\title{
JOBBAN FEJLESZTHETŐK A KOGNITÍV KÉPESSÉGEK AZ ELEVE JOBB KÉPESSÉGÜ TANULÓK ESETÉBEN?
}

Szerzők:

Szabóné Balogh Ágota

Gál Ferenc Főiskola

Első szerző e-mail címe:

szaboneagota@gmail.com

\section{Lektorok:}

Fest Sarolta

Gál Ferenc Főiskola

Katona Krisztina

Gál Ferenc Főiskola

Mezö Ferenc

Eszterházy Károly Egyetem

Nemes Magdolna

Debreceni Egyetem

Szabóné Balogh Ágota (2017): Jobban fejleszthetők a kognitív képességek az eleve jobb képességü tanulók esetében? Különleges Bánásmód, III. évf. 2017/3. szám, 55-66. DOI 10.18458/KB.2017.3.55

\begin{abstract}
Absztrakt
Háttér és célkitüzések: Az oktatás, a tanulás folyamatának egyik fontos eleme a tanulók kognitív képességeinek a megismerése és fejlesztése. A vizsgálat célja a felső tagozatos tanulók figyelmének, emlékezetének, gondolkodásának 5. osztályban és 8. osztályban mért képességszintek közötti korreláció vizsgálata. Feltételezés: a kísérleti csoportban, az elővizsgálatban mutatott képességszint és az utóvizsgálatban mért képességszint között korreláció van. A jobb képességü tanulók jobban fejlődtek a vizsgálat alatt, mint a gyengébb képességüek. Módszer: A vizsgálat keretében olyan felső tagozatos tanulók ( $\mathrm{n}=174$ fö) vettek részt, akik számára négy tanéven keresztül longitudinális képességfejlesztés történt. A résztvevők emlékezetének, figyelmének, gondolkodásának fejlödésének nyomon követése a tehetséggondozásban ismert tesztek segítségével történt. Eredmények: A figyelemnél, a gondolkodásnál és az emlékezetnél erős pozitív korreláció tapasztalható. Következtetések: Az erős, pozitív korreláció arra utal, hogy a kezdeti előnyök megjelennek a fejleszthetőség során, a jobb képességü tanulók nagyobb fejlődést mutatnak.
\end{abstract}

Kulcsszavak: kognitív képességek, figyelem, emlékezet, gondolkodás

Diszciplína: pszichológia, pedagógia

\section{Abstract}

Background and aims: An important issue of teaching and learning processes is how to assess and develop students' cognitive abilities. The aim of the study to examine the correlation between in class 5 and 8 class measured skill levels' attention, memory and thinking. Assumption: The correlation is between the pre-tested skills level and the post tested skills level in the pilot group. The students with better skills have developed better 
during testing than the students with lower skills. Method: During the survey I monitored the progression of students brought under a group $(n=174)$ who in development activities took part in 4 years. The follow-up of the participants' memory, attention, and thinking was done with tests known in talent management. Results: There is strong, positive correlation in attention, memory and thinking. Discussion: The strong positive correlation indicates that the students with better skills show greater development than the students with lower skills. The initial benefits appear in point of the chance of development.

Keywords: cognitive abilities, attention, memory, thinking

Disciplines: Pedagogy, psychology

A pedagógusok fontos feladata a tanulók kognitív képességeinek megismerése és fejlesztése, ugyanakkor állandó vizsgálati lehetőséget biztosít- lásd például a korai kutatásokat (Piaget, 1950; Spearman, 1927), de napjainkban is számos vizsgálat (például Racsmány és társai, 2001; Csapó, 2003; Kelemen, Csíkos, Steklács, 2005; Csépe, 2005; Hoskins \& Fredrikson, 2008; Janacsek és társai, 2009; Molnár, 2011; Mező \& Mezö, 2014, Mohai, Szabó 2014) tủzi ki célul e képességek megismerését. Balogh (2006) szerint, a kognitív képességek (figyelem, emlékezet, megértés, problémamegoldó gondolkodás) fejlesztése nélkül nem alakíthatók ki hatékony, intenzív tanulási módszerek. A tanulás hatékonyságát fejlesztő, mérő kutatások (Csapó, 2003; Csíkos, 2007; Revákné, 2010; Greiff, S. és társai, 2013; Revákné és társai, 2013, Molnár, 2013) mind az induktív gondolkodásra az analógiás gondolkodásra, az önszabályozó tanulásra, a metakognicióra, a tanulás tanulására, a problémamegoldó gondolkodás fejlesztésére, problémamegoldási stratégiákra kiterjedtek. A komplex munkamemória müködését Racsmány, 2007, Táncos, Janacsek, Németh (2014); Kovács és mtsai, 2016 egyaránt vizsgálták. Greenfield (2009) szerint a vizuális figyelem, a párhuzamos feldolgozás képessége, valamint a téri-vizuális kapacitás is fejlődik az internet használatának gyarapodásával. A Szegedi Tudományegyetem Oktatáselméleti kutatócsoportja napjainkban is méri az általános iskolás tanulók kognitív képességeit, elektronikus teszttelés segítségével. Dávid és társai (2014) az infokommunikációs eszközök gyakorlati használatának hatását vizsgálták a tanulói képességekre.

Az eltérő képességü tanulók differenciált fejlesztése szintén központi kérdése az oktatási folyamatnak. A differenciális pszichológia felhívta a figyelmet az azonos életkorú gyermekek eltérő szükségleteire, fejlődési ütemükre, habitusukra, motivációjukra, érdeklődésükre, készségeikre, tanulási stílusukra, tanulási ütemükre, tanulási orientációjukra. Nem szabad figyelmen kívül hagyni az eltérő szociokulturális környezetből adódó eltéréseket és hátrányokat, melyek alátámasztják a tanulók differenciált fejlesztésének szükségességét. A téma vizsgálatával hazai és külföldi kutatók egyaránt foglalkoztak, mint például: Báthory (1985), Tóth (2000), Réthyné (2003), Balogh (2006), Papp, (2006), Rock és társai (2008), McQuarrie, McRae, Stack-Cutler (2008).

Érdekes kérdésként merül fel, hogy az eltérő képességű tanulók longitudinális fejlesztés során a képességszintek között milyen kapcsolatok vannak, mely képességü gyerekek fejlődnek jobban.

A vizsgálat célja a felső tagozatos tanulók figyelmének, emlékezetének, gondolkodásának 5 . osztályban (elővizsgálat) és 8. osztályban (utóvizsgálat) mért képességszintek közötti korreláció vizsgálata, feltételezve, hogy a jobb képességü tanulók, jobban fejlődtek. 


\section{MÓDSZER}

A négy évig tartó longitudinális vizsgálat keretében öt alkalommal történt adatfelvétel a vizsgálati csoporttal. Az első mérés 5. osztály szeptemberében történt, a további négy mérésre 5., 6., 7. és 8. osztály végén, májusban került sor. A csoportban, a fejlesztés során, az első vizsgálat elvégzése után a tanulók informatika alapú képességfejlesztésben vettek részt. A fejlesztés időtartama: 4 év (5-8. osztály); intenzitása: 1 óra/hét; helyszíne: iskolai számítógépterem. Hardver szükséglet: számítógép az összes tanuló számára, tanárgép, projektor, interaktív tábla.

A program során alkalmazott szoftverek a következők voltak: a számítógépeken Windows operációsrendszer, Office, egyszerü képszerkesztő és filmkészítő program, interaktív táblaszoftver, rejtvénykészítő program, gondolattérképkészítő program, böngésző, internet elérést lehetővé tevő böngésző. A foglalkozások során komplex feladatokat alkalmaztunk, melyek során előtérbe helyeztük az összefüggések megláttatását a tanult és az új ismeretek között; a lényegkimelést ábrák képek, kulcsfogalmak segítségével és a tanultak felidézését, a logikus, kritikus, megértő gondolkodás, a figyelem, a vizuális és a verbális memória fejlesztését. A fejlesztő programban a fejlesztés tantárgyi blokkokhoz kapcsolódott: matematika, történelem, magyar, természetismeret (és 7-8. osztályban földrajz, biológia, fizika) tárgyakhoz. A kutatásba bevont iskolákban, a kísérleti csoportokban a bemeneti tesztek alapján képességfejlesztő foglalkozásokon vettek részt a tanulók. Az eredmények alapján történt a tanulásszervezés, esetenként a differenciálás. A csoportmunka során a csoportok kialakítását minden esetben a fejlesztés tartalmi célja határozta meg, így képességeik szerint, vagy haladási tempójuk alapján, heterogén illetve homogén csoportokban dolgoztak a tanulók. A vizuális és verbális emlékezet fejlesztése során számítógéppel segített programozott oktatást, multimédiás, interaktív eszközöket, oktatócsomagokat, felhasználói programokat alkalmaztunk, illetve az internet sokoldalú használata segítette a fejlesztést. A kísérleti csoportban részt vevő tanulók megfigyelése a pedagógusok által folyamatosan történt. A pedagógusokkal és a gyerekekkel történő konzultáció lehetősége a longitudinális vizsgálat ideje alatt szintén folyamatos volt. Jelen tanulmányban az elő és utóvizsgálat eredményeinek, korrelációjának vizsgálata került bemutatásra.

\section{Minta}

A vizsgálati mintát 174 általános iskola felső tagozatába járó tanuló alkotta. A bemeneti mérés (elővizsgálat) idején a tanulók 5. osztályosak (kísérleti: átlag életkor: 10,37, szórás: 0,53; 89 fiú, 85 lány), a kimeneti mérésnél (utóvizsgálat) 8. osztályosak voltak. A bemeneti mérések alapján - a tanulók alsó 50\% és felső 50\% (medián alapján) tekintve - bemenetkor 46 tanuló (27 fiú, 19 lány) gyenge és 128 fö (62 fiú, 66 lány) jobb képességü volt. A tanulók héthét vidéki település iskolájából kerültek ki, a mintavétel széleskörü, de nem reprezentatív. A szülők a vizsgálatról szóló tájékoztatáson vettek részt, majd írásbeli hozzájárulásukkal engedélyezték a tanulók vizsgálatban való részvételét. A tanulókkal kapcsolatos adatokat az adatvédelmi és személyiségi jogi elvek betartásával kezeltük.

\section{Eszközök}

A kognitív képességek vizsgálatára a hazai tehetségkutatásokban alkalmazott vizsgáló eljárásokat választottunk (Balogh, 2004). A tesztek kiválasztását a hazai tehetséggondozó programokban való eredményes alkalmazásuk indokolta (Balogh, 2004; Balogh 2006).

A figyelem vizsgálatára a Bourdon-próbát alkalmaztuk, melynek a lényege, hogy soronként át kell húzni az „a” és ,„e" betűket, egy értelmetlen betű és szótagsorban. Két perce van erre a tanulóknak. A figyelemkoncentrációt, fáradékonyságot vizsgálja. Mind a figyelem mennyiségét (átnézett szöveg hossza), mind a figyelem minőségét (hibázások százalékos aránya) értékeljük (Szilágyi, 1987, Czigler, 2005.). 
A rövidtávú emlékezetet két teszttel vizsgáltuk, az egyik a verbális, másik a vizuális memóriát vizsgálta. A verbális memória tesztje huszonöt szóból áll. Ezek háromszor történő elolvasása után, a tanulóknak emlékezetből 3 perc alatt le kell írniuk azokat a szavakat, amelyekre emlékeznek (Ádám és társai, 1990). A vizuális memória vizsgálata alakzatokra való emlékezés és formafelismerés segítségével történt. A tesztben kilenc ábrát kell a tanulóknak megjegyezniük, majd emlékezetből a másik lapon húsz ábrából kiválasztani egy perc alatt, azokat melyekre emlékeznek. (Kósáné, 1988)

A problémamegoldó gondolkodás vizsgálata két teszttel történt, amelyek a szabályszerüség felismerésén alapultak. A matematika logika tesztje a Meili-féle számsorok, ahol húsz számsorozatnak a szabályát kell a tanulóknak felismerni, majd a következő két tagját a vizsgálati papírra leírni (Kósáné, 1988). Vizuális problémamegoldás tesztelése ábrasor segítségével megvalósítható. A Cattel féle soralkotási feladat segítségével a szabályszerüség felismerését, annak a fejlettségét lehet mérni. Nyolc soralkotási feladat található a tesztlapon. A tanulóknak meg kell keresniük, hogy a sorba melyik ábra illik bele (Kósáné, 1988).

\section{EREDMÉNYEK}

\section{Leíró statisztikák}

A figyelem, az emlékezet, a gondolkodás méréséhez használt tesztek \%-os teljesítményértékeinek (helyes válaszok aránya) leíró statisztikák láthatóak az 1., 2., 3. táblázatban.

1. táblázat. Figyelem leíró statisztikái. Forrás:Szerző.

\begin{tabular}{|c|c|c|c|c|c|c|c|c|c|c|c|c|c|}
\hline \multirow{2}{*}{\multicolumn{2}{|c|}{ Csoport }} & \multicolumn{4}{|c|}{ Fiú $N=89$} & \multicolumn{4}{|c|}{ Lány $\mathrm{N}=85$} & \multicolumn{4}{|c|}{ Teljes $\mathrm{N}=174$} \\
\hline & & Átlag & Szórás & Min & Max & Átlag & Szórás & Min & Max & Átlag & Szórás & Min & Max \\
\hline \multirow{5}{*}{$\begin{array}{l}\infty \\
\infty \\
\infty \\
=0 \\
: \Xi \\
\sum\end{array}$} & 1. mérés & 98,47 & 2,26 & 92,21 & 100,00 & 98,48 & 2,40 & 91,56 & 100,00 & 98,47 & 2,32 & 91,56 & 100,00 \\
\hline & 2. mérés & 98,52 & 2,17 & 92,86 & 100,00 & 98,59 & 2,16 & 92,21 & 100,00 & 98,56 & 2,16 & 92,21 & 100,00 \\
\hline & 3. mérés & 98,63 & 2,05 & 92,86 & 100,00 & 98,76 & 1,92 & 92,21 & 100,00 & 98,69 & 1,98 & 92,21 & 100,00 \\
\hline & 4. mérés & 99,77 & 0,46 & 98,05 & 100,00 & 99,79 & 0,51 & 98,05 & 100,00 & 99,78 & 0,49 & 98,05 & 100,00 \\
\hline & 5. mérés & 99,96 & 0,16 & 99,35 & 100,00 & 99,97 & 0,14 & 99,35 & 100,00 & 99,96 & 0,15 & 99,35 & 100,00 \\
\hline \multirow{5}{*}{ 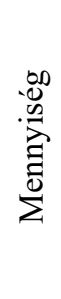 } & 1. mérés & 58,79 & 17,01 & 19,48 & 88,31 & 59,72 & 14,99 & 22,73 & 100,00 & 59,25 & 16,01 & 19,48 & 100,00 \\
\hline & 2. mérés & 64,96 & 17,29 & 25,97 & 96,10 & 66,10 & 15,00 & 31,17 & 100,00 & 65,52 & 16,18 & 25,97 & 100,00 \\
\hline & 3. mérés & 69,62 & 17,39 & 29,87 & 100,00 & 70,92 & 15,00 & 36,36 & 100,00 & 70,25 & 16,23 & 29,87 & 100,00 \\
\hline & 4. mérés & 75,81 & 16,48 & 34,42 & 100,00 & 76,68 & 14,26 & 40,91 & 100,00 & 76,24 & 15,40 & 34,42 & 100,00 \\
\hline & 5. mérés & 81,65 & 14,56 & 45,45 & 100,00 & 82,45 & 12,71 & 46,10 & 100,00 & 82,04 & 13,65 & 45,45 & 100,00 \\
\hline \multirow{5}{*}{ 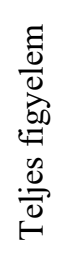 } & 1. mérés & 78,63 & 8,58 & 57,47 & 93,83 & 79,10 & 7,69 & 58,12 & 100,00 & 78,86 & 8,14 & 57,47 & 100,00 \\
\hline & 2. mérés & 81,74 & 8,70 & 61,36 & 98,05 & 82,35 & 7,64 & 65,58 & 100,00 & 82,04 & 8,18 & 61,36 & 100,00 \\
\hline & 3. mérés & 84,12 & 8,74 & 63,96 & 99,68 & 84,84 & 7,54 & 68,18 & 100,00 & 84,47 & 8,16 & 63,96 & 100,00 \\
\hline & 4. mérés & 87,79 & 8,22 & 67,21 & 100,00 & 88,24 & 7,16 & 70,45 & 100,00 & 88,01 & 7,70 & 67,21 & 100,00 \\
\hline & 5. mérés & 90,80 & 7,28 & 72,73 & 100,00 & 91,21 & 6,36 & 73,05 & 100,00 & 91,00 & 6,83 & 72,73 & 100,00 \\
\hline
\end{tabular}


KÜLÖNLEGES BÁNÁSMÓD, III. ÉVF. 2017/3.

\section{2. táblázat. Emlékezet leíró statisztikái}

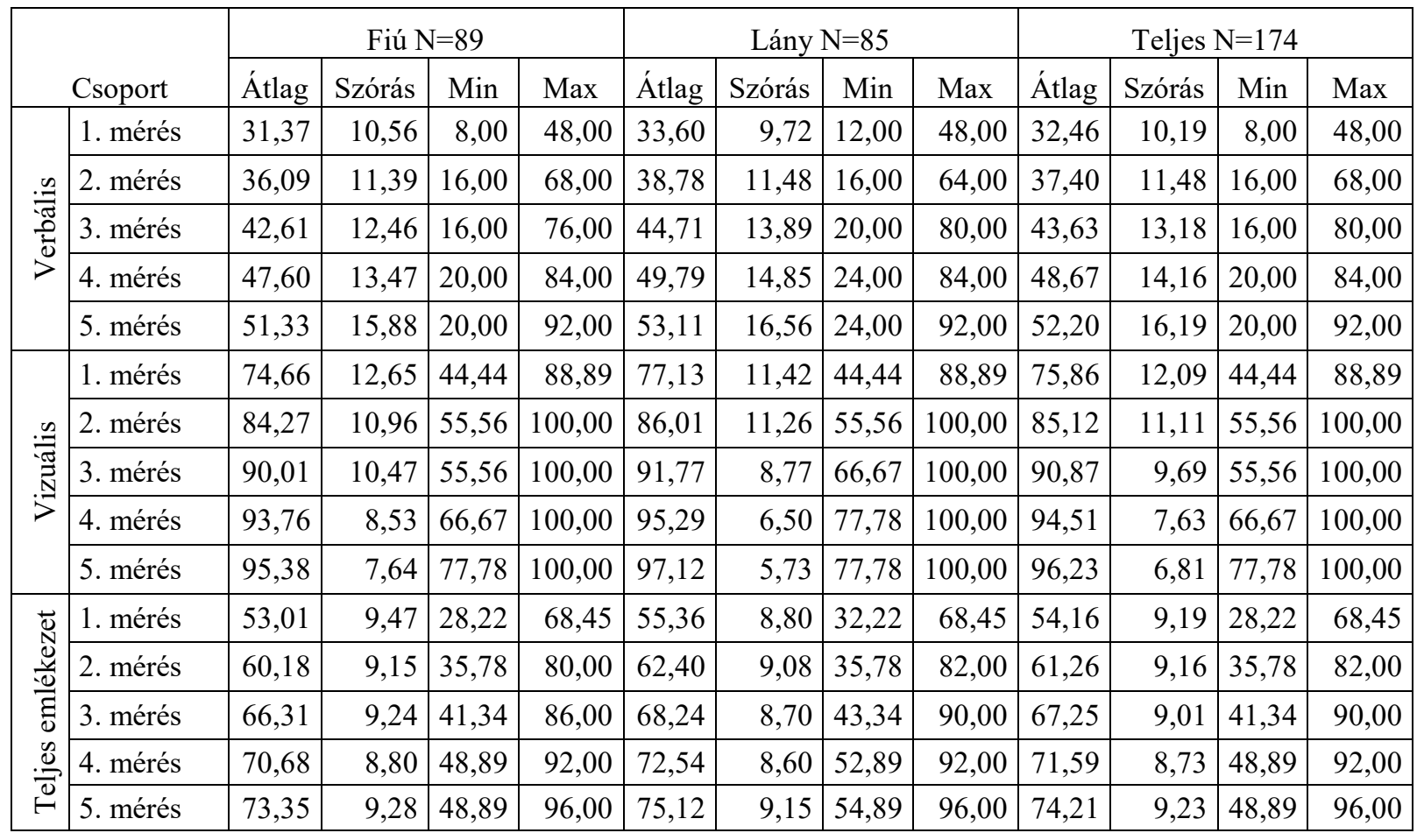

3. táblázat. Gondolkodás leíró statisztikái

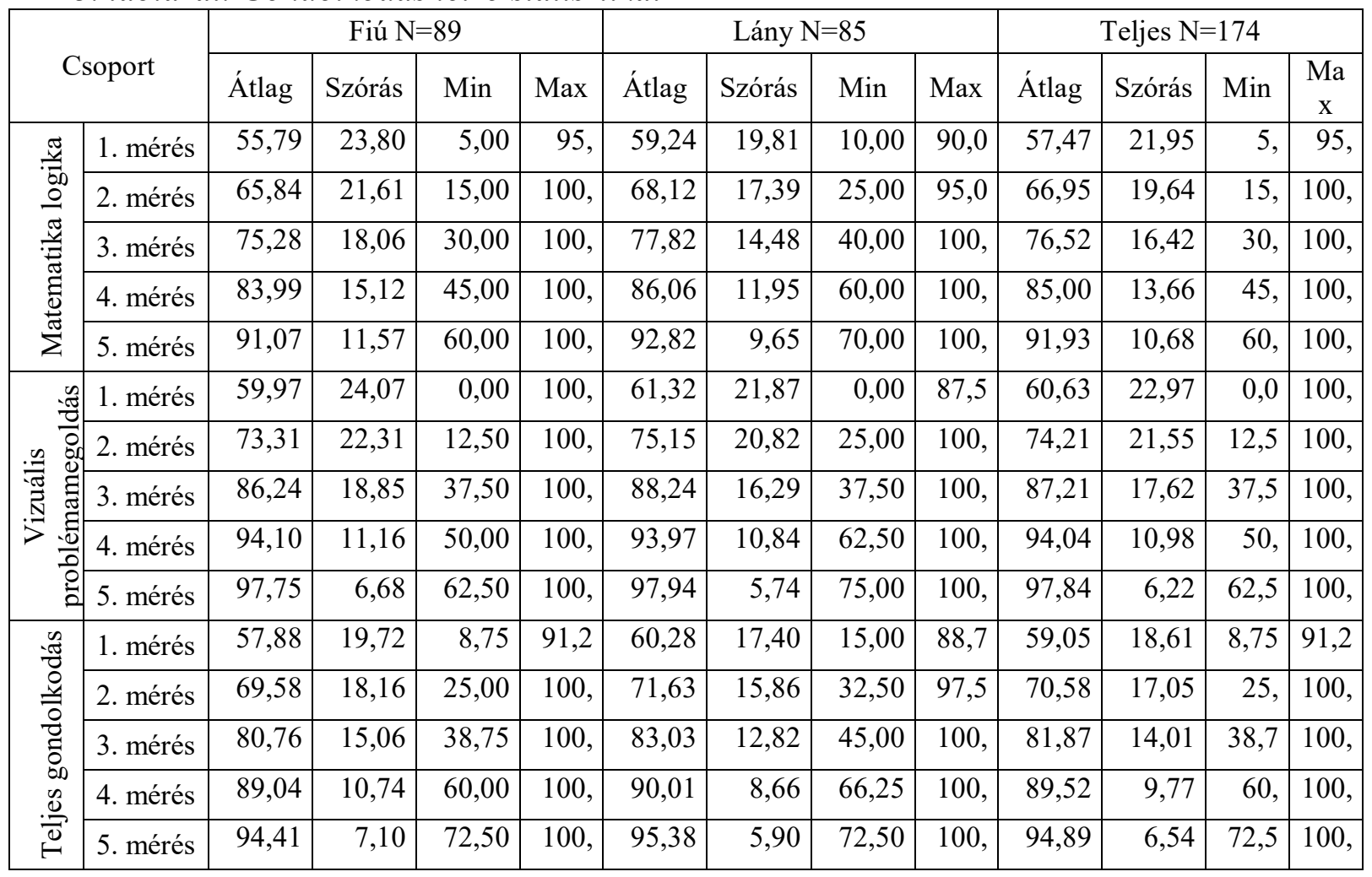

A figyelem, az emlékezet és a gondolkodás területén egyaránt nagyok a különbségek a legkisebb ( $\mathrm{min})$ és a legnagyobb (max) teljesítményértékek között, illetve látható, hogy a szórás minden mérési időpontban elég nagy (1., 2., 3. táblázatok). Tehát nagyok a különbségek a gyermekek teljesítményei között. 


\section{Összehasonlító vizsgálatok}

A vizsgált mintát a bemeneti mérések alapján mind a figyelem, mind az emlékezet, mind a gondolkodás területén 4-4 csoportra bontottam. Teljesítmény alapján az alsó $25 \%$-a (43 fö) a leggyengébb (1. csoport), és a felső $25 \%$ (43 fö) a legjobb (4. csoport) mérési eredményt elért tanulók.

A két csoport (1. és 4.) teljesítménye, a normalitás hiánya miatt Mann-Whitney próbával lett összehasonlítva (4. táblázat).

\section{4. táblázat. Mann-Wihitney próba eredményei}

\begin{tabular}{|c|c|c|c|c|c|c|}
\hline \multirow{2}{*}{ Statisztika } & \multicolumn{2}{|c|}{ Figyelem } & \multicolumn{2}{c|}{ Emlékezet } & \multicolumn{2}{c|}{ Gondolkodás } \\
\cline { 2 - 7 } & $\begin{array}{c}\text { elö- } \\
\text { vizsgálat }\end{array}$ & $\begin{array}{c}\text { utó- } \\
\text { vizsgálat }\end{array}$ & $\begin{array}{c}\text { elö- } \\
\text { vizsgálat }\end{array}$ & $\begin{array}{c}\text { utó- } \\
\text { vizsgálat }\end{array}$ & $\begin{array}{c}\text { elö- } \\
\text { vizsgálat }\end{array}$ & $\begin{array}{c}\text { utó- } \\
\text { vizsgálat }\end{array}$ \\
\hline Mann-Whitney U & 0,000 & 0,000 & 0,000 & 57,500 & 0,000 & 48,000 \\
\hline Wilcoxon W & 946,000 & 946,000 & 946,000 & 1003,500 & 946,000 & 994,000 \\
\hline Z & $-7,988$ & $-8,355$ & $-8,013$ & $-7,502$ & $-7,996$ & $-8,023$ \\
\hline $\begin{array}{c}\text { szignifikancia szint } \\
\text { (2-tailed) }\end{array}$ & 0,000 & 0,000 & 0,000 & 0,000 & 0,000 & 0,000 \\
\hline
\end{tabular}

a. Változók csoportosítása: csoport $(1,4)$

A 4. táblázatban látható, hogy szignifikáns különbség $(\mathrm{p}<0,05)$ van a két csoport elö- és utóvizsgálata esetében egyaránt.

Az 1. csoporton és a 4. csoporton belül, külön-külön az elövizsgálat és az utóvizsgálat eredményei a Wilcoxon próbával lettek összehasonlítva (5. táblázat).

5. táblázat. Wilcoxon próba eredményei

\begin{tabular}{|c|c|c|c|c|c|c|}
\hline \multirow{2}{*}{ Statisztika } & \multicolumn{3}{|c|}{$\begin{array}{c}\text { 1 csoport } \\
\text { elón }\end{array}$} & elós utóvizsgálatának összehasonlítása & \multicolumn{3}{c|}{ 4. csoport és utóvizsgálatának összehasonlítása } \\
\cline { 2 - 7 } & figyelem & emlékezet & gondolkodás & figyelem & emléket & gondolkodás \\
\hline$Z$ & $-5,712^{\mathrm{b}}$ & $-5,715^{\mathrm{b}}$ & $-5,716^{\mathrm{b}}$ & $-5,647^{\mathrm{b}}$ & $-5,717^{\mathrm{b}}$ & $-5,721^{\mathrm{b}}$ \\
\hline $\begin{array}{c}\text { szignifikancia } \\
\text { szint (2-tailed) }\end{array}$ & 0,000 & 0,000 & 0,000 & 0,000 & 0,000 & 0,000 \\
\hline
\end{tabular}

a. Wilcoxon Signed rang teszt

b. Negatív rang.

$\mathrm{Az}$ 5. táblázatban látható csoportonként a figyelem, emlékezet, gondolkodás elő és utóvizsgálati eredményei, melyek között minden esetben szignifikáns különbség $(p<0,05)$ látható, tehát az elővizsgálatnak az eredményei alacsonyabbak, mint az utóvizsgálaté..

\section{Figyelem}

A vizsgálatnál az 1. mérés a bemeneti, ez elővizsgálat, az 5. mérés a kimeneti, az utóvizsgálat.

A 6. táblázatban látható, hogy figyelem minőségénél, a két időpont között gyenge korreláció $(\mathrm{r}=0,564)$ tapasztalható, még a figyelem mennyiségénél $(\mathrm{r}=0,919)$ erős korreláció van. A teljes figyelemnél $(r=0,914)$ erős korreláció van. Mind a három esetben szignifikáns különbség $(\mathrm{p}<0,05)$ tapasztalható, tehát valószínüsíthető, hogy a kapcsolat nem a véletlen müve. 
6. táblázat. Figyelem elö és utóvizsgálata közötti korrelációs vizsgálat

\begin{tabular}{|c|c|c|c|c|}
\hline \multicolumn{2}{|c|}{$\begin{array}{c}\text { Korreláció } \\
\mathrm{N}=174\end{array}$} & $\begin{array}{c}\text { Figyelem } \\
\text { minőség 5. } \\
\text { mérés }\end{array}$ & $\begin{array}{c}\text { Figyelem } \\
\text { mennyiség } \\
5 . \text { mérés }\end{array}$ & $\begin{array}{c}\text { Teljes figyelem 5. } \\
\text { mérés }\end{array}$ \\
\hline \multirow{2}{*}{$\begin{array}{c}\text { Figyelem minőség } \\
\text { 1. mérés }\end{array}$} & Pearson korreláció & $0,564^{* *}$ & 0,060 & 0,070 \\
\cline { 2 - 5 } & szignifikancia & 0,000 & 0,420 & 0,370 \\
\hline \multirow{2}{*}{$\begin{array}{c}\text { Figyelem mennyiség } \\
\text { 1. mérés }\end{array}$} & Pearson korreláció & $-0,02$ & $0,919^{* *}$ & $0,919^{* *}$ \\
\cline { 2 - 5 } & szignifikancia & 0,800 & 0,000 & 0,000 \\
\hline \multirow{2}{\text{Teljesfigyelem}}{\begin{tabular}{c} 
1. mérés \\
\cline { 2 - 5 }
\end{tabular}} & Pearson korreláció & 0,060 & $0,913^{* *}$ & $0,914^{* *}$ \\
\cline { 2 - 5 } & szignifikancia & 0,420 & 0,000 & 0,000 \\
\hline
\end{tabular}

**. $p<0,01$ szinten szignifikáns

*. $p<0,05$ szinten szignifikáns

A figyelem mennyiségénél, a teljes figyelemnél az erős pozitív korreláció arra utal, hogy a jobb képességủek nagyobb fejlődést mutatnak, mint a gyengébb képességüek (4. táblázat, 4. ábra). A kezdeti előnyök megjelennek a fejleszthetőség tekintetében. A figyelem minőségének a fejlődésénél nincs olyan nagy különbség a jobb és a gyengébb képességü gyerekek között, itt gyenge volt a korreláció.

1. ábra. Teljes figyelem elö (1.) és utó (5.) vizsgálatánál mért teljesitménynek összehasonlitása. (Forrás: a Szerzö)

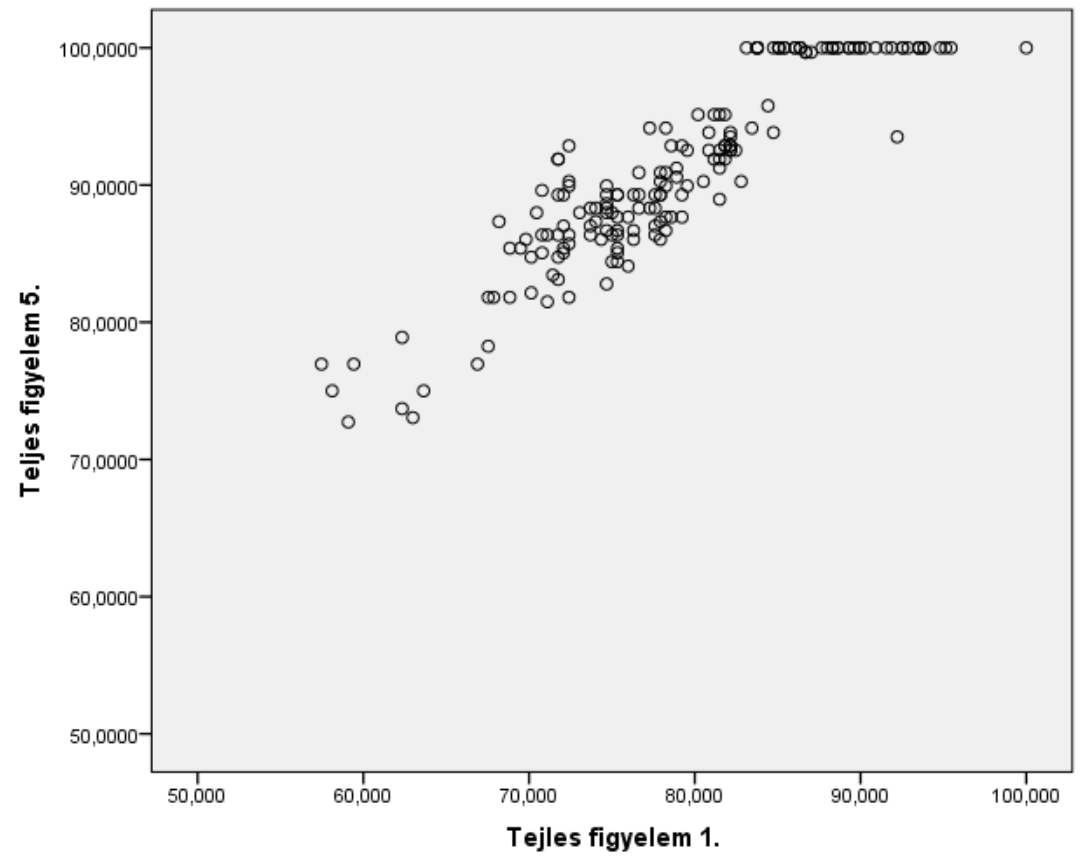

\section{Emlékezet}

A vizsgálatnál az 1. mérés a bemeneti, ez elővizsgálat, az 5. mérés a kimeneti, az utóvizsgálat. 
A 7. táblázatban látható, hogy a verbális memóriánál $(\mathrm{r}=0,845)$, a vizuális memóriánál $(\mathrm{r}=0,718)$, a teljes memóriánál $(\mathrm{r}=0,758)$ erős korreláció van. Mind a három esetben szignifikáns különbség $(\mathrm{p}<0,05)$ van, tehát valószínüsíthető, hogy a kapcsolat nem a véletlen müve. Az erős pozitív korreláció arra utal, hogy a jobb képességüek nagyobb fejlődést mutatnak, mint a gyengébb képességüek 7. táblázat, 2. ábra). A kezdeti előnyök megjelennek a fejleszthetőség tekintetében.

7. táblázat. Emlékezet elö és utóvizsgálata közötti korrelációs vizsgálat

\begin{tabular}{|c|c|c|c|c|}
\hline \multicolumn{2}{|c|}{$\begin{array}{c}\text { Korreláció, } \\
\mathrm{N}=174\end{array}$} & $\begin{array}{c}\text { Verbális } \\
\text { memória } \\
5 . \text { mérés }\end{array}$ & $\begin{array}{c}\text { Vizuális } \\
\text { memória } \\
5 . \text { mérés }\end{array}$ & $\begin{array}{c}\text { Teljes } \\
\text { memória } \\
5 . \text { mérés }\end{array}$ \\
\hline \multirow{2}{*}{$\begin{array}{c}\text { Verbális memória 1. } \\
\text { mérés }\end{array}$} & Pearson korreláció & $0,845^{* *}$ & $0,295^{* *}$ & $0,850^{* *}$ \\
\cline { 2 - 5 } & szignifikancia & 0,000 & 0,000 & 0,000 \\
\hline \multirow{2}{*}{$\begin{array}{c}\text { Vizuális memória 1. } \\
\text { mérés }\end{array}$} & Pearson korreláció & $0,196^{* *}$ & $0,718^{* *}$ & $0,437^{* *}$ \\
\cline { 2 - 5 } & szignifikancia & 0,010 & 0,000 & 0,000 \\
\hline \multirow{2}{*}{$\begin{array}{c}\text { Teljes emlékezet 1. } \\
\text { mérés }\end{array}$} & Pearson korreláció &, $598^{* *}$ & $0,636^{* *}$ & $0,758^{* *}$ \\
\cline { 2 - 5 } & szignifikancia & 0,000 & 0,000 & 0,000 \\
\hline
\end{tabular}

**. $p<0,01$ szinten szignifikáns

*. $p<0,05$ szinten szignifikáns

2. ábra. A teljes emlékezet elö (1.) és utó (5.) vizsgálatánál mért teljesítménynek összehasonlítása. (Forrás: a Szerzö)

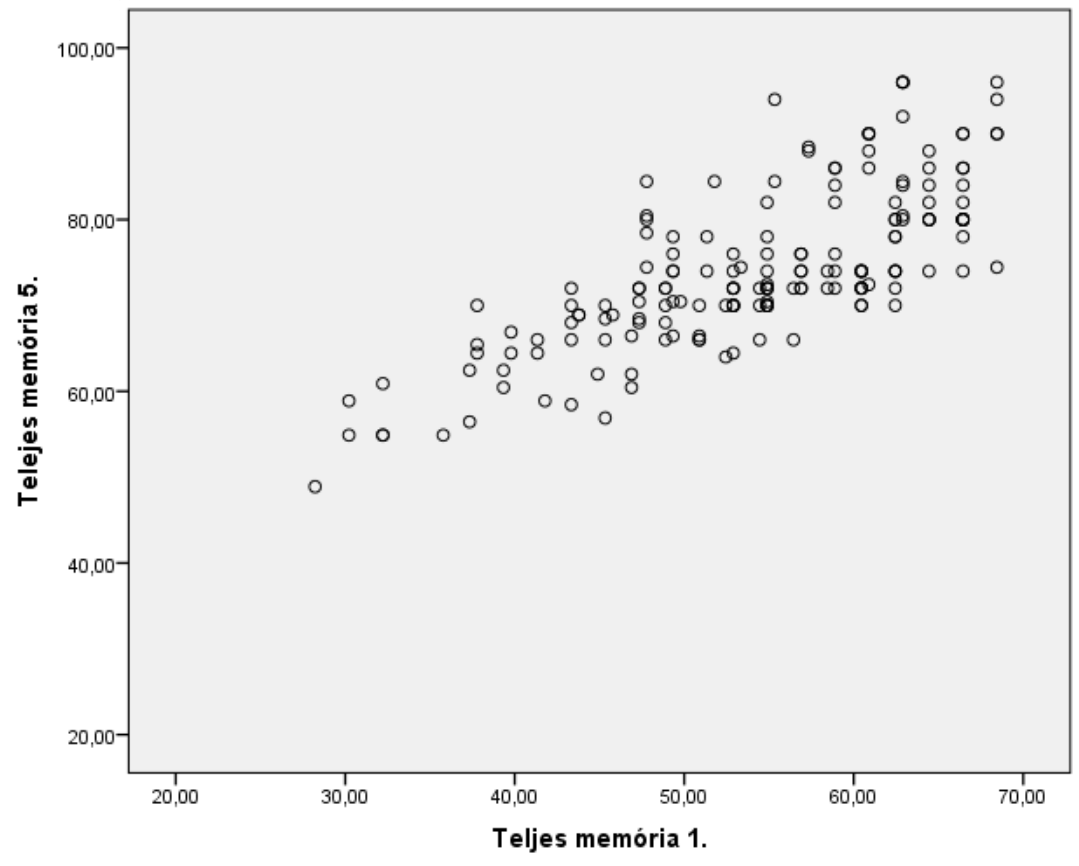

\section{Gondolkodás}

A vizsgálatnál az 1 . mérés a bemeneti, ez elővizsgálat, az 5 . mérés a kimeneti, az utóvizsgálat. 
A 8. táblázatban látható, hogy a matematika logikánál $(\mathrm{r}=0,859)$, a gondolkodásnál $(\mathrm{r}=0,810)$ erős korreláció van. A vizuális problémamegoldásnál $(\mathrm{r}=648)$ gyengébb a korreláció. Mind a három esetben szignifikáns különbség $(\mathrm{p}<0,05)$ van, tehát valószínüsíthető, hogy a kapcsolat nem a véletlen müve. A matematika logikánál, a gondolkodásnál erős pozitív korreláció arra utal, hogy a jobb képességüek nagyobb fejlődést mutatnak, mint a gyengébb képességüek (8. táblázat, 3. ábra). A kezdeti előnyök megjelennek a fejleszthetőség tekintetében. A vizuális problémamegoldásnál gyengébb korreláció van, kisebb a különbség a jobb és a gyengébb képességü tanulók között.

8. táblázat. Gondolkodás elö és utóvizsgálata közötti korrelációs vizsgálat

\begin{tabular}{|c|c|c|c|c|}
\hline \multicolumn{2}{|c|}{$\begin{array}{c}\text { Korreláció } \\
\mathrm{N}=174\end{array}$} & $\begin{array}{c}\text { Matematika } \\
\text { logika } \\
5 . \text { mérés }\end{array}$ & $\begin{array}{c}\text { Vizuális } \\
\text { problémamegoldás } \\
5 . \text { mérés }\end{array}$ & $\begin{array}{c}\text { Gondolkodás } \\
5 . \text { mérés }\end{array}$ \\
\hline $\begin{array}{c}\text { Matematika logika 1. } \\
\text { mérés }\end{array}$ & Pearson korreláció & $0,859^{* *}$ & $0,198^{* *}$ & $0,795^{* *}$ \\
\cline { 2 - 5 } & szignifikancia & 0,000 & 0,010 & 0,000 \\
\hline $\begin{array}{c}\text { Vizuális } \\
\text { problémamegoldás 1. } \\
\text { mérés }\end{array}$ & Pearson korreláció & $0,300^{* *}$ & $0,648^{* *}$ & $0,553^{* *}$ \\
\cline { 2 - 5 } & szignifikancia & 0,000 & 0,000 & 0,000 \\
\hline $\begin{array}{c}\text { Gondolkodás (teljes) } \\
\text { 1. mérés }\end{array}$ & Pearson korreláció & $0,692^{* *}$ & $0,517^{* *}$ & $0,810^{* *}$ \\
\cline { 2 - 5 } & szignifikancia & 0,000 & 0,000 & 0,000 \\
\hline
\end{tabular}

**. $p<0,01$ szinten szignifikáns

*. $p<0,05$ szinten szignifikáns

6. ábra. A gondolkodás elö (1.) és utó (5.) vizsgálatánál mért teljesitménynek összehasonlitása. (Forrás: a Szerzö)

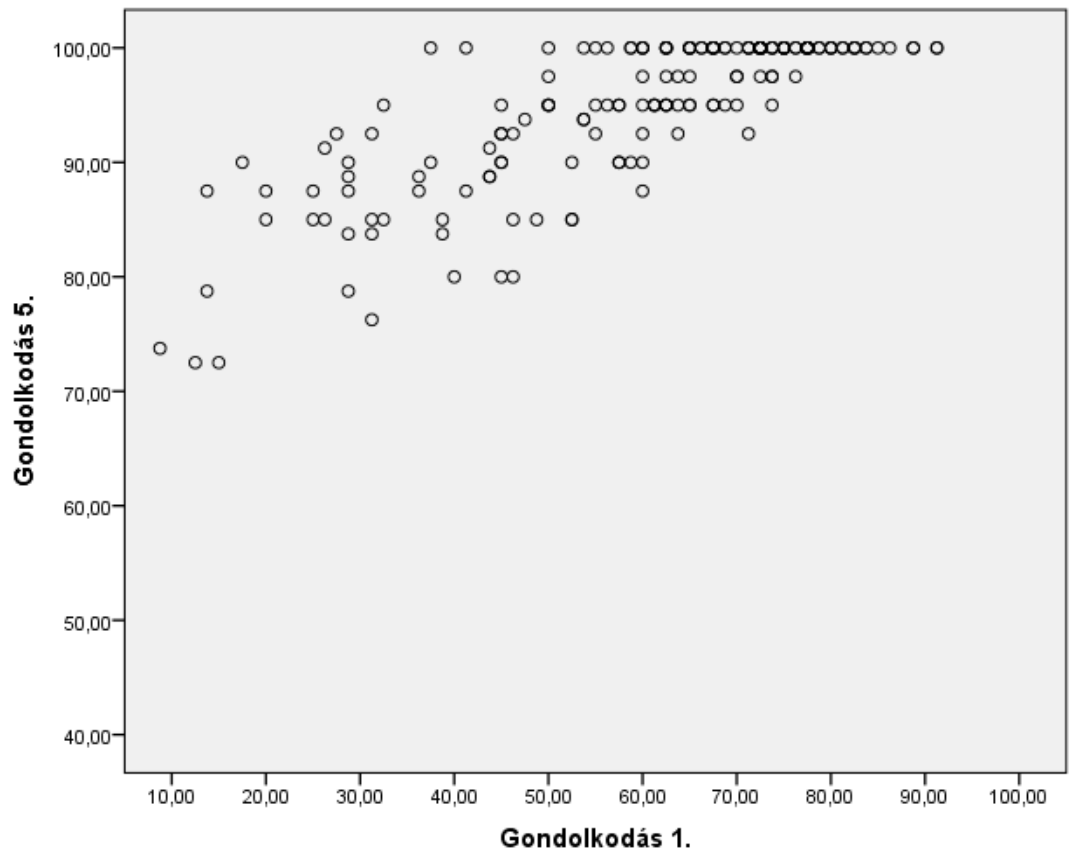

\section{Megvitatás és korlátok}

Feltételezzük, hogy a kísérleti csoportban, az elővizsgálatban mutatott képességszint és az utóvizsgálatban mért képességszint között korreláció van. A jobb képességü tanulók jobban fejlődtek a vizsgálat alatt, mint a gyengébb képességüek. 
A kísérleti csoportban, az elővizsgálatban mutatott teljes figyelem, teljes emlékezet, teljes gondolkodás területén mért képességszint és az utóvizsgálatban mért képességszint között erős korreláció, összefüggés van (a figyelemnél $\mathrm{r}=0,914$, a gondolkodásnál $\mathrm{r}=0,810$, a memóriánál $\mathrm{r}=0,758)$. Az erős pozitív korreláció arra utal, hogy a jobb képességü tanulók nagyobb fejlődést mutatnak, mint a gyengébb képességüek. A kezdeti előnyök megjelennek a fejleszthetőség tekintetében. A figyelem minőségénél $(\mathrm{r}=0,564)$ és a vizuális problémamegoldás $(\mathrm{r}=0,648)$ esetében gyengébb a korreláció a többihez képest. A figyelem minőségnél, a vizuális problémamegoldásnál a gyengébb tanulók általában a vizsgálat végénél közelítettek a 100\%-hoz, a jobbak viszont már 7 . osztály végén elérték ezt a teljesítményt.

A vizsgálat korlátjának tekinthető, hogy a tesztek esetében a 100\%-os teljesítményhez a verbális memóriánál 25 , még a vizuálisnál mindössze 9-re, a vizuális gondolkodásnál 8-ra, a matematika logikánál 20, helyes válaszra a volt szükség, a figyelem esetében pedig mennyiségileg $174 \mathrm{db}$ jó betü felismerésre. Így a vizsgálatokban számolnunk kell a kifáradás, a motivációvesztés lehetőségével és a koncentrálási képesség csökkenésével is. S nem szabad elfelejteni, hogy mindezen korlátok ellenére is fejlődés tapasztalható, és a jobb képességü tanulók jobban fejlődtek.

A kísérletben résztvevő tanulókat sok szempontból lettek vizsgálva (figyelem, emlékezet, gondolkodás, intelligencia, iskolai motiváció, iskolai orientáció, kreativitás), s a pedagógusokkal való konzultációk során is sok információt kaptunk, de a tanulók, szocioökonómiai státuszát nem szürtünk, a későbbiekben ilyen vizsgálatokkal érdemes lenne kiegészíteni a méréseket (v. ö. Ribiczey, 2010), s akár élethosszig tartó tanulás (Kálmán, 2015, 2016) aspektusából is vizsgálni a képességek és teljesítmények viszonyát.

\section{KONKLÚZIÓK}

A mérési eredmények következtében a jobb képességü tanulók a figyelem, az emlékezet és a gondolkodás területén egyaránt jobban teljesítettek. A leginkább a figyelem mennyiségénél, majd a matematika logikánál, és a verbális memóriánál.

A kísérletben részt vevő tanulók 7 különböző iskolából kerültek ki (1 megyeszékhely, 4 közepes város, 2 kisváros), így elmondható, hogy az eltérő lakosságú települések esetén is hasonló eredmények lettek.

\section{IRODALOM}

Ádám, P., Balogh, L., Miláth, L-né, Nádudvari, I-né (1990). Általános pszichológia, Tankönyvkiadó, Budapest, 1990. 81.

Balogh, L. (2004): Iskolai tehetséggondozás. Kossuth Egyetem Kiadó, Debrecen.

Balogh, L. (2006): Pedagógiai pszichológia az iskolai gyakorlatban. Urbis Könyvkiadó, Budapest.

Báthory, Z. (1985): Tanitás és tanulás. Tankönyvkiadó, Budapest.

Czigler, I. (2005): A figyelem pszichológiája. Akadémiai Kiadó, Budapest

Csapó, B. (2003). A képességek fejlödése és iskolai fejlesztése. Akadémiai Kiadó, Budapest.

Csépe, V. (2005). Kognitív fejlödés - neuropszichológia. Gondolat Kiadó, Budapest.

Csíkos, Cs. (2007): Metakogníció. A tudásra vonatkozó tudás pedagógiája. Műszaki Kiadó, Budapest.

Dávid, M., Estefánné Varga, M., Hatvani, A., Taskó, T., Doner, L., Soltész, P. (2014). Az infokommunikációs eszközök gyakori használatának hatása a tanulói képességekre. In Bárdos, J.- Kis-Tóth, L., Racsko, R. (szerk.). Változó életformák, régi és új tanulási környezetek. Líceum Kiadó, Eger. 63-76. 
Greenfield, P. (2009): Technology and informal education: What is taught, what is learned. Science, 323, 68-71

Greiff, S., Wüstenberg, S., Molnár, Gy., Fischer, A., Funke, J. és Csapó, B. (2013): Complex Problem Solving in Educational Contexts - Something beyond g: Concept, Assessment, Measurement Invariance, and Construct Validity. Journal of Educational Psychology, 105. 2. sz. 364-379

Hoskins, B. ,Fredriksson, U. (2008). Learning to learn: What is it and can it be measured? European Communities, Italy.

Janacsek, K., Tánczos, T., Mészáros, T., Németh, D. (2009). A munkamemória új magyar nyelvü neuropszichológiai mérőeljárása: a hallási mondatterjedelem teszt (HTM). Magyar Pszichológiai Szemle, 64. (2.) 385-406.

Kálmán, A. (2015): Study of correlations between efficient learning habits and the study achievement indicator. In: Kamel Hawwash, Christophe Léger (szerk.): Proceedings of the 43rd SEFI Annual Conference 2015: Diversity in engineering educat ion: an opportunity to face the new trends of engineering. Brussels: European Society for Engineering Education (SEFI). 8 p.

Kálmán, A. (2016): Learning - in the New Lifelong and Lifewide Perspectives. Tampere: Tampere University of Applied Sciences

Kelemen, R., Csíkos, Cs., Steklács, J. (2005). A matematikai problémammegoldást kísérő metakognitív stratégiák vizsgálata a hangosan gondolkodtatás és a videomegfigyelés eszközeivel. Magyar Pedagógia. 105. 4. sz. 343-358.

Kósáné Ormos. V. (1988): Fejlödéslélektani gyakorlatok I., Feladatok. Tankönyvkiadó, Budapest.

Kovács, K., Faragó, B., Kövi, Zs., Rózsa, S., Dávid, M. (2016): A rövid távú emlékezet és a munkamemória online mérése: Corsi, számterjedelem és N-vissza. Magyar Pszichológia Szemle, 71. 1/4. 73-90.

McQuarrie, L., McRae, P., Stack-Cutler, H. (2008): Differentiated instruction provincial research review. Edmonton: Alberta Initiative for School Improvement

Mezö, K., Mezö, F. (2014). The IPOO-model of creative learning and the students' information processing characteristics. Horizons of Psychology, 23. 136-144.

Mohai, K., Szabó, Cs. (2014). A munkamemória vizsgálata. Gyógypedagógiai Szemle, 62. 226-232.

Molnár, Gy. (2011). Számítógépes játékon alapuló képességfejlesztés egy pilot vizsgálat eredményei. Iskolakultúra. 6-7. 3-11.

Molnár, Gy. (2013). Mindennapi helyzetekben alkalmazott problémamegoldó stratégiák, Iskolakultúra, 2013/7-8, 31-43.

Papp, G. (2006). A differenciálás megközelítésének néhány szempontja. Fejlesztő Pedagógia 2006/6. szám, 12-16.

Piaget, J. (1950). The psychology of intelligence. Harcourt Brace. New York.

Racsmány, M. (2007): A fejlődés zavarai és vizsgálómódszerei. Neuropszichológiai diagnosztikai módszerek. Akadémiai Kiadó, Budapest. 11-39.

Racsmány, M., Lukács, Á., Pléh, Cs., Király, I. (2001): Some cognitive tools for word learning: The role of working memory ang goal preference. Behavioral and Brain Sciences, 24. 6. sz. 1115- 1117.

Réthy, E-né (2003): Motiváció, tanulás, tanitás. Nemzeti Tankönyvkiadó, Budapest

Revákné Markóczi, I. (2010): A 9-10 éves tanulók természettudományos problémamegoldó stratégiájának vizsgálata. Magyar Pedagógia, 110. 1. sz. 53-71.

Revákné Markóczi, I., Máth, J., Huszti, A. és Pollner, K. (2013). A természettudományos problémamegoldás metakogníciójának mérése a felső oktatatásban, Magyar Pedagógia, 113. évf. 4. sz. 221-241 
Ribiczey, N. (2010). Környezeti hatások és intellektuális fejlődés - Különböző megközelítések a környezet releváns aspektusainak megragadására. Gyógypedagógai Szemle 2010/1 Letöltve: 2014.210 .2 11-én: http://www.prae.hu/prae/gyosze.php?menu_id=102\&jid=31\&jaid=457)

Rock, M., Gregg, M., Ellis, M., Gable, R. A. (2008): REACH: A framework for differentiating classroom instruction. Preventing School Failure, 52 (2), 31-47.

Spearman, C. (1927): The abilities of man. MacMillan, London.

Szegedi Tudományegyetem Oktatáselméleti kutatócsoport csoport: http://edia.hu/ (megtekintve 2016. 12.11.)

Szilágyi, K. (1987): A Brickenkamp: d2 (Figyelemvizsgáló eljárás). Munkaügyi Kutatóintézet, Budapest

Táncos, T., Janacsek, K., Németh, D. (2014). A munkamemória és végrehajtó funkciók kapcsolata az iskolai teljesítménnyel. Alkalmazott Pszichológia, 14 (2), 55-57.

Tomlinson, C. A., Strickland, C. A. (2005). Differentiation in practice: A resource guide for differentiating curriculum, grades 9-12. Alexandria, VA: ASCD.

Tóth, L. (2000). Pszichológia a tanításban. Pedellus Tankönyvkiadó, Debrecen. 